\begin{tabular}{|c|c|c|}
\hline BIODIK & $\begin{array}{c}\text { BIODIK: Jurnal IImiah Pendidikan Biologi } \\
\text { ISSN 2580-0922 (online), ISSN 2460-2612 (print) } \\
\text { Volume 7, Nomor 01, Tahun 2021, Hal. 33-42 } \\
\text { Available online at: } \\
\text { https://online-journal.unja.ac.id/biodik }\end{array}$ & BIODIK $(Q)$ \\
\hline
\end{tabular}

Research Article open 2 Access

\title{
Pengembangan Booklet Budidaya Jamur Edible Sebagai Bahan Ajar Mikologi
}

\author{
(Development of Edible Mushroom Cultivation Booklet as Mycology Teaching Materials)
}

\author{
Harlis, Retni S.Budiarti, Desfaur Natalia \\ JI. Raya Jambi-Ma.Bulian KM.15 Mendalo Indah-Muaro Jambi-Indonesia \\ Corresponding Authors: harlisbiologi@yahoo.co.id
}

\begin{tabular}{|c|c|}
\hline Informasi Artikel & ABSTRACT \\
\hline $\begin{array}{l}\text { Submit: } 09-12-2020 \\
\text { Diterima: } 26-02-2021 \\
\text { Dipublikasikan: } 14-03-2021\end{array}$ & $\begin{array}{l}\text { This study aims to develop an edible mushroom cultivation booklet in the mycology } \\
\text { course. The method used in this research is research and development using the } \\
\text { ADDIE model. This research was conducted with the stages of analysis, design, } \\
\text { development, implementation, and evaluation. Based on the results of the study, it } \\
\text { shows that the feasibility of the booklet used is declared feasible according to the } \\
\text { results of media validation and material validation by the validator team. On the } \\
\text { results of the first media validation with a score of } 75 \% \text { "good" and the second media } \\
\text { validation is } 90 \% \text { "very good". While the results of the validation of the first material } \\
\text { with a score of } 70 \text { "good" and the result of the second validation is } 90 \text { "very good". } \\
\text { After the assessment was carried out by the validator team, then the booklet was } \\
\text { tested with small groups and large groups of biology education students. Based on } \\
\text { the results of the small group student response test, it was found that } 91.5 \% \text { was } \\
\text { included in the "very good" category, and the results of the large group student } \\
\text { responses obtained a percentage of } 98.3 \% \text { included in the "very good" category. The } \\
\text { results showed that the edible mushroom cultivation booklet developed was suitable } \\
\text { for use as a learning resource, able to foster interest and entrepreneurial spirit for } \\
\text { Biology Education Students of Jambi University. } \\
\text { Key words: Booklet, cultivation, Edible Mushrooms }\end{array}$ \\
\hline Penerbit & ABSTRAK \\
\hline $\begin{array}{l}\text { Program Studi Pendidikan } \\
\text { Biologi, Fakultas Keguruan dan } \\
\text { Ilmu Pendidikan, Universitas } \\
\text { Jambi }\end{array}$ & $\begin{array}{l}\text { Penelitian ini bertujuan mengembangkan booklet budidaya jamur edible pada mata } \\
\text { kuliah mikologi. Metode yang digunakan pada penelitian ini yaitu penelitian dan } \\
\text { pengembangan dengan menggunakan model } A D D I E \text {. Penelitian ini dilakukan dengan } \\
\text { tahap analysis, design, development, implementation, dan evaluation. Berdasarkan } \\
\text { hasil penelitian menunjukkan bahwa kelayakan terhadap booklet yang digunakan } \\
\text { dinyatakan layak sesuai hasil dari validasi media dan validasi materi oleh tim } \\
\text { validator. Pada hasil validasi media ke-1 dengan skor } 75 \% \text { "baik" dan validasi media } \\
\text { yang ke-2 yaitu } 90 \% \text { "sangat baik". Sedangkan hasil validasi materi yang ke-1 } \\
\text { dengan skor } 70 \text { "baik" dan hasil validasi yang ke-2 yaitu } 90 \text { "sangat baik". Setelah } \\
\text { dilakukan penilaian oleh tim validator selanjutnya booklet dilakukan ujicoba dengan } \\
\text { kelompok kecil dan kelompok besar terhadap mahasiswa pendidikan biologi. } \\
\text { Berdasarkan hasil dari uji respon mahasiswa kelompok kecil diperoleh persentase } \\
91,5 \% \text { termasuk dalam kategori "sangat baik", dan hasil respon siswa kelompok } \\
\text { besar diperoleh persentase } 98,3 \% \text { yang termasuk dalam kategori "sangat baik". Hasil } \\
\text { penelitian menunjukkan bahwa booklet budidaya jamur edible yang dikembangkan } \\
\text { layak digunakan sebagai sumber belajar, mampu menumbuhkan minat dan jiwa } \\
\text { entreprenership bagi Mahasiswa Pendidikan Biologi Universitas Jambi. } \\
\text { Kata kunci: Booklet, budidaya, Jamur Edible }\end{array}$ \\
\hline
\end{tabular}




\section{PENDAHULUAN}

Jamur Edible merupakan jamur yang digunakan untuk bahan makanan. Jamur ini memiliki cita rasa yang enak dan aman untuk dikonsumsi sehingga jamur ini menjadi suatu komoditas untuk dibudidayakan. Contoh jamur edible yang banyak dikonsumsi oleh masyarakat, antara lain jamur kuping (Auricularia polytrica), jamur kancing (Agaricus bisporus), jamur merang (Volvariella volvacea), jamur shiitake (Lentinula edodes), dan jamur tiram (Pleurotus ostreatus).Selain itu, jamur edible banyak mengandung vitamin dan mineral yang penting bagi tubuh antara lain, mengandung vitamin $\mathrm{B}$ dan $\mathrm{C}$. Sedangkan kandungan mineral yang penting dalam jamur antara lain, Pospor (P), zat besi (Fe),kalium $(\mathrm{K})$, natrium ( $\mathrm{Na}$ ), dan Kalsium (Ca) (Achmad, dkk., 2013:25). Jamur edible merupakan salah satu materi mikologi yang diberikan kepada mahasiswa yang mengambil mata kuliah mikologi.

Pada materi Mikologi ini terdapat berbagai kompetensi yang harus dikuasai dan menjadi capaian pembelajaran oleh mahasiswa. Oleh karena itu, sebagian besar mahasiswa menganggap materi Mikologi sulit untuk dipahami. Ada beberapa alasan materi Mikologi yang diajarkan dianggap sulit untuk dipahami. Pertama, kompetensi ataupun sub bagian pokok dari materi mikologi banyak menampilkan isi bacaan yang sulit untuk dipahami untuk peserta didik. Kedua,media pembelajaran tentang budidaya jamur edible pada dasarnya dalam bentuk buku budidaya jamur, buku budidaya tersebut sedikit menampilkan gambar sehingga pembaca menjadi bosan dalam membaca buku budidaya tersebut dan konten isi perlu dilakukan dengan penyesuaian kurikulum. Ketiga, masih kurangnya media pembelajaran yang dapat dijadikan pegangan mahasiswa maupun dosen dalam proses pembelajaran budidaya jamur edible. Keempat, budidaya jamur edible membutuhkan waktu yang lama, sehingga perlu ada media pembelajaran dalam bentuk bacaan yang banyak menampilkan gambar dan sedikit tulisan yang membantu menjelaskan secara cepat dan mudah dipahami. Hal ini menyebabkan mahasiswa kurang terlatih dalam membangun pengetahuan dan membudidaya mengenai mikologi, menyebabkan ketidak efisienan waktu. Prastowo (2012:17) menjelaskan bahwa segala materi yang disusun secara sistematis yang menampilkan keutuhan materi tersebut dan memuat kompetensi sebagai tujuan rencana pembelajaran yang diimpelemtasikan selama proses pembelajaran disebut media pembelajaran.

Solusi dari permasalahan tersebut antara lain dengan adanya media pembelajaran yang mampu mengajarkan cara budidaya jamur edible dengan menggunakan media booklet. Booklet merupakan buku yang berukuran kecil yang memiliki halaman paling sedikit 5 halaman dan maksimal 48 halaman yang menyajikan berbagai visual seperti: huruf, foto, gambar, garis atau lukisan. Sedangkan isi pada booklet bersifat tegas, jelas dan mudah dipahami (Mintarti, 2011). Penyajian booklet yang menggunakan banyak warna dan gambar akan memberikan tampilan yang menarik (Pralisaputri, $d k k$, 2016).

Di perguruan tinggi, booklet juga dapat digunakan oleh mahasiswa agar lebih memahami konsep dari suatu materi yang diajarkan. Dikti (2009) menjelaskan bahwa agar lebih memahami konsep materi, perlu adanya media yang dirancang para ahli dibidangnya yang digunakan mahasiswa dalam perkuliahan. menurut Arsyad (2011:15) penggunaan media pembelajaran dalam proses belajar mengajar berfungsi untuk membangkitkan keinginan dan minat yang baru, membangkitkan motivasi, memberikan pengalaman lebih nyata, dan meningkatkan rangsangan dalam kegiatan belajar, dan membawa berpengaruh pada psikologis terhadap peserta didik. Tersedianya booklet yang tersusun secara sistematis akan sangat memungkinkan mahasiswa untuk belajar menguasai berbagai macam kompetensi yang diharuskan secara maksimal. Depdiknas (2008) menjelaskan bahwa penyediaan 
booklet mempertimbangkan berbagai tuntutan kurikulum sehingga tersedia booklet yang sesuai dengan kebutuhan dan menjadi laternatif pilihan dalam kegiatan pembelajaran yang lebih bervariasi. Selain itu akan memudahkan pendidik menyampaikan materi yang diajarkan.

Proses pembelajaran tidak terlepas dari media pembelajaran seperti media cetak yang berisi suatu ilmu pengetahuan tertentu dalam bentuk tertulis. Sebagai sarana belajar yang dipakai kegiatan belajar mengajar, bahan ajar dalam bentuk booklet sangat diperlukan dalam menunjang proses pembelajaran diberbagai tingkatan pendidikan dari sekolah dasar maupun perguruan tinggi. Suwarni (2015:89-90) menyatakan kesediaan media pembelajaran akan menjadikan kegiatan pembelajaran lebih efektif dan efisien. Media pembelajaran terdiri atas berbagai macam kelompok, salah satunya media pembelajaran bahan ajar cetak. Dengan adanya media cetak ini memudahkan guru atau peserta didik untuk mencapai tujuan pembelajaran.

\section{METODE PENELITIAN}

Penelitian ini mengadopsi jenis penelitian dan pengembangan dengan menggunakan model pengembangan Analysis, Design, Development, Implementation, dan Evaluation (ADDIE) yang dikembangkan oleh Branch (2009). Tahapan dalam penelitian dan pengembangan ini sebagai berikut:

a. Tahap Analisa (Analysis)

Struktur dari tahapan ini terdiri atas dua tahap yaitu:

1) Analisis kurikulum.

Analisis dilakukan terhadap RPS yang dibuat untuk melihat seberapa jauh rencana pembelajaran yang sudah ada dalam mata kuliah mikologi dalam mencapai capaian pembelajaran yang menjadi output mata kuliah. Selain itu analisis kurikuum dijadikan acuan untuk referensi dalam pengembangan produk yang akan dibuat.

2) Analisis sumber belajar.

Analisis sumber belajar merupakan bagian dalm upaya untuk mengetahui apasaja yang dibutuhkan pada materi jamur edible sebagai isi atau konten dari booklet yang akan dikembangkan pada mata kuliah mikologi. Analisis ini juga sebagai refleksi untuk mengetahui kekurangan terhadap kompenen perangkat pembelajaran yang selama ini digunakan. sehingga permasalahan yang mendasar dapat diketahui dan diperbaiki sebagai landasan perbaikan sehingga produk yang mencakup keseluruhan aspek yang dibutuhkan.Dari hasil analisis kurikulum dan sumber belajar nantinya dihasilkan produk booklet yang bisa mencakup segala aspek yang telah di analisis sebelumnya.

b. Tahap Perancangan (Design)

Tahapan desain (design) dilakukan perencanaan buku ajar materi budidaya jamur edible. Tahapan ini menghasilakn rancangan awal dari produk yang akan di validasi sehingga nantinya mampu mencapai semua kompetensi yang ingin dicapai selama proses pembelajaram. Semnetara itu rancangan materi meliputi keseluruhan konten materi jamur edible yang harus dipelajari oleh mahasiswa pendidikan Biologi dalam mencapai kompetensi yang telah di tetapkan dalam silabus.

c. Tahap Pengembangan (Develop)

Tahap ini dimaksudkan untuk memperbaiki produk awal yang telah dibuat dengan mempertimbangkan hasil validasi oleh validator berupa masukan dan revisi secara berkesinambungan sehingga dihasilkan booklet yang valid untuk digunakan.

d. Tahap Implementasi (Implement)

Implementasi dilakukan untuk menguji produk yang dihasilkan pada pengguna sesungguhnya. Implementasi juga sebagai bentuk upaya dalam melihat kelayakan produk yang dihasilkan. 
Implementasi produk pada uji kelompok kecil untuk melihat keterbacaan sebelum dilakukan uji pada kelas sebenarnya. Sehingga nantinya didapatkan hasil booklet yang benar-benar teruji kelayakannnya. Angkat respon mahasiswa diberikan diakhir pembelajaran sebagai bentuk respon terhadap penggunaan booklet.

\section{e. Tahap Evaluasi (Evaluation)}

Tahap ini dilakukan disetiap langkah prosedur pengembangan sebagai upaya perbaikan yang bertujuan mememperbaiki setiap langkah yang dilakukan, Sehingga proses evaluasi dan refleksi memudahkan untuk memperbaiki setiap tahap yang dilalui.

Data dalam penelitian ini berupa data kualitatif dan kuantitatif. Tanggapan oleh pakar atau ahli (validator) menjadi masukan bagi perbaikan booklet yang dikembangkan. Sementara itu persentase tanggapan mahasiswa dilihat dari rata-rata angket yang telah diberikan pada akhir pembelajaran dengan jumlah 3 SKS dengan bobot 2 teori dan 1 praktikum. Angket dibuat dengan menggunakan skala likert dengan pilihan penilaian 1 sampai dengan 4 . Subjek ujicoba penelitian ini adalah mahasiswa yang sudah mengontrak mata kuliah Mikologi yang berjumlah 34 orang mahasiswa.

Langkah selanjutnya setelah data terkumpul yang dilakukan adalah analisis data. Adapun data yang akan dianalisis adalah data kualitatif dan data kuantitatif. Data kualitatif diolah dari saran validator media. Sedangkan data yang dianalisis secara kuantitatif didapat dari skor penilaian terhadap kelayakan media yang dikembangkan. Apabila persentase media memenuhi $60 \%$ atau lebih media tersebut dianggap layak atau mencapai kriteria kelayakan.

a. Analisis angket oleh validator media dan validator materi

Angket yang digunakan dalam penelitian ini menggunakan skala likert. Menurut Sudaryono (2013:49) skala likert digunakan untuk mengukur sikap, pendapat dan persepsi seseorang atau sekelompok mengenai suatu kejadian atau adanya gejala sosial. Karena pada penelitian ini peneliti melihat respon dari narapidana anak terhadap buku populer yang dikembangkan, maka interval jawaban angketnya sebagai berikut:

Tabel 1. Bobot skor setiap jawaban instrumen

\begin{tabular}{ccc}
\hline Skala Nilai & $\begin{array}{c}\text { Rentang Persentase } \\
(\%)\end{array}$ & Instrumen Jawaban \\
\hline 4 & $75<$ skor $\leq 100$ & Sangat Baik \\
3 & $50<$ skor $\leq 74$ & Baik \\
2 & $25<$ skor $\leq 49$ & Tidak Baik \\
1 & $0<$ skor $\leq 24$ & Sangat Tidak Baik \\
\hline
\end{tabular}

Menghitung presentase dari tiap-tiap indikator, dengan menggunakan rumus:

$$
\% \text { Kevalidan }=\frac{\text { Jumlah Skor Yang diperoleh }}{\text { Jumlah Skor Maksimum }} \times 100 \%
$$

Keterangan :

- Jumlah skor yang diperoleh: Jumlah item $\times$ bobot penilaian untuk kriteria yang dipilih.

- Jumlah skor maksimum: Bobot skor penilaian maksimum tiap item $\times$ Jumlah item deskriptor $\times$ jumlah responden 


\section{b. Analisis respon mahasiswa}

Penelitian pengembangan ini dilakukan ujicoba untuk pengambilan data persepsi atau respon dari mahasiswa pada ujicoba kelompok kecil dan kelompok besar tentang media dengan bantuan angket yang juga diolah dengan skala pengukuran likert dengan 4 interval jawaban.

\section{HASIL DAN PEMBAHASAN}

Penelitian ini akan menghasilkan "Booklet Budidaya Jamur Edible" untuk mata kuliah mikologi bagi mahasiswa pendidikan Biologi. Penelitian ini berupa tingkat kevalidan booklet yang dikembangan dengan menggunakan model pengembangan ADDIE (Analysis, Design, Development, Implementation, Evaluation). Adapun hasil penelitian pengembangan antara lain sebagai berikut:

\section{Tahap Analisis (Analysis)}

Pada tahapan analisis yaitu meliputi analisis kurikulum dan analisis sumber belajar. Analisis kurikulum yaitu pada mata kuliah Mikologi yang menunjukkan mahasiswa dituntut untuk mampu menjelaskan tentang jamur, ciri-ciri jamur dan pemanfaatannya. Untuk mencapai itu semua perlu adanya bahan ajar, salah satunya yaitu dalam bentuk booklet yang mampu meningkatkan minat belajar mahasiswa untuk dapat belajar secara mandiri dalam mencapai kompetensi tersebut.

Selanjutnya untuk analisis sumber belajar dalam penelitian ini yaitu tentang materi jamur yang dikonsumsi (jamur edible). Dalam pembelajaran mikologi selama ini, komponen bahan ajar yang digunakan yaitu masih menggunakan buku yang sudah lama dan kurang terbarui yang tidak mengikuti dengan perkembangan zaman. Dalam analisis sumber belajar juga dilihat dari setiap komponen bahan ajar yang akan dikembangkan menjadi booklet.

\section{Tahap Perancangan (Desain)}

Pada tahap kedua yaitu tahap perancangan bahan ajar yang mengikuti format buku yang sudah baku dalam menghasilkan booklet. Perancangan booklet meliputi keseluruhan materi jamur edible yang akan diajarkan dan menjadi panduan dalam mencapai kompetensi yang tercantum pada Rencana Pembelajaran Semester (RPS).

\section{Tahap Pengembangan (Development)}

Tahap pengembangan merupakan tahap proses penilaian terhadap booklet budidaya jamur edible yang dinilai dari segi materi dan segi media, serta tingkat kepraktisan yang dinilai oleh mahasiswa. Dalam penilaian booklet budidaya jamur edible dilakukan oleh dua validator yang memiliki latar belakang kependidikan yang relevan sesuai dengan booklet budidaya jamur edible yang dikembangkan. Adapun hasil validasi materi dan validasi media antara lain sebagai berikut :

\section{a. Hasil Validasi Ahli Materi}

Produk yang dikembangkan berupa booklet yang berjudul budidaya jamur edible sebagai sumber belajar untuk mahasiswa pendidikan biologi yang kemudian divalidasi oleh ahli materi. Validasi materi dilakukan sebanyak dua kali, tiap komentar atau saran dari validator diperbaiki hingga produk layak untuk diujicobakan. Validasi materi berfungsi untuk melihat kesesuaian materi yang terdapat dalam booklet budidaya jamur edible yang telah dikembangkan. Hasil validasi materi dapat dilihat pada gambar 1. 


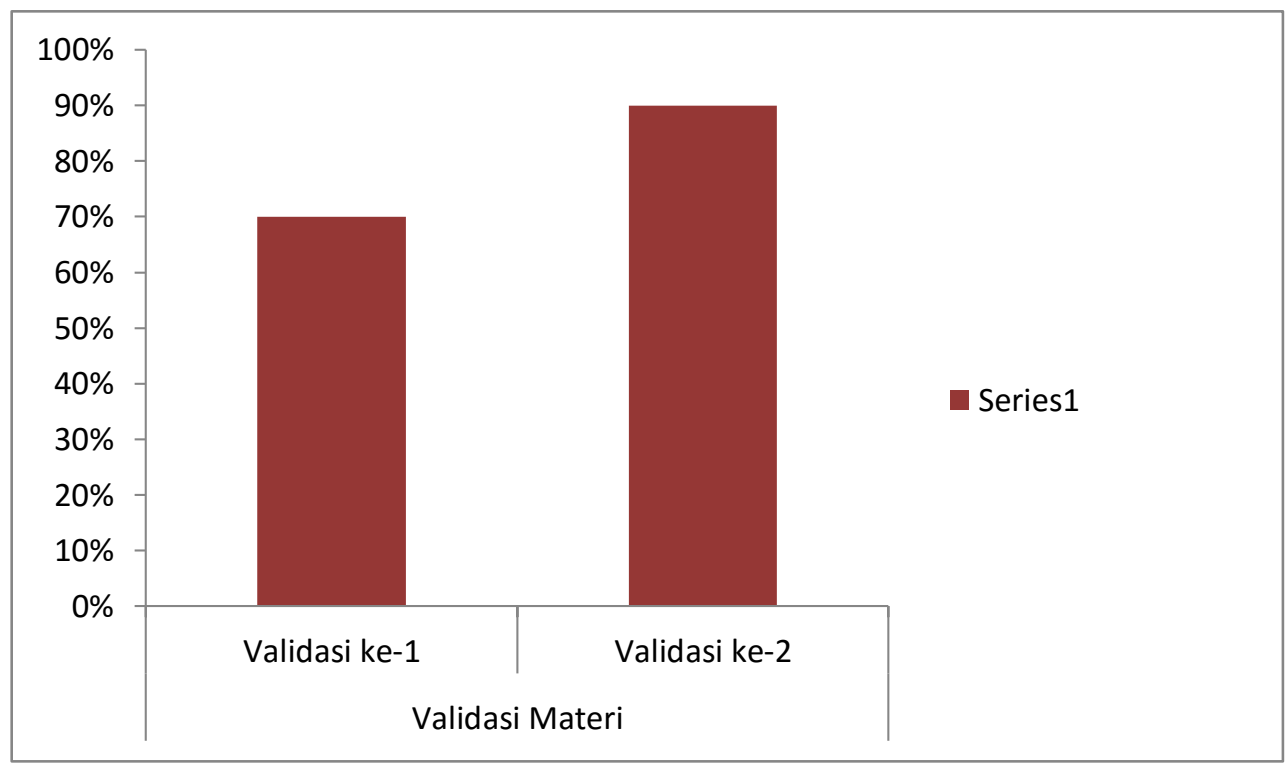

Gambar 1. Hasil validasi materi

Berdasarkan hasil validasi materi pada grafik diperoleh skor keseluruhan sebesar 28 dengan persentase $70 \%$ yang termasuk pada kategori "Baik" ini merupakan hasil validasi tahap ke-I. Sedangkan hasil validasi tahap ke-II diperoleh skor keseluruhan sebesar 36 dengan persentasi $90 \%$ yang termasuk kedalam ketegori "Sangat Baik".

b. Hasil Validasi Ahli Media

Produk yang dikembangkan berupa booklet yang berjudul budidaya jamur edible sebagai sumber belajar untuk mahasiswa pendidikan biologi yang kemudian divalidasi oleh ahli media. Validasi media dilakukan sebanyak dua kali, tiap komentar atau saran dari validator diperbaiki hingga produk layak untuk diujicobakan. Adapun hasil validasi media oleh validator dapat dilihat pada gambar 2.

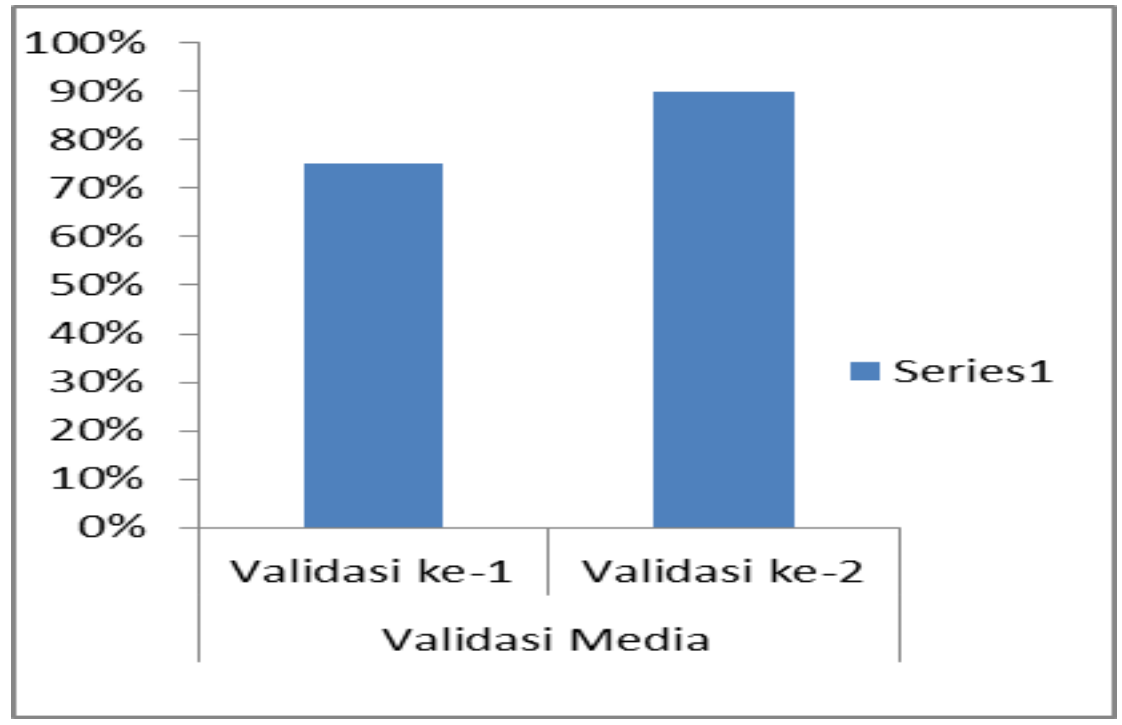

Gambar 2. Hasil validasi media 
Berdasarkan hasil validasi media pada Tabel 5.2 diperoleh skor keseluruhan sebesar 30 dengan persentase $75 \%$ yang termasuk pada kategori "Baik" ini merupakan hasil validasi tahap ke-I. Sedangkan hasil validasi tahap ke-II diperoleh skor keseluruhan sebesar 36 dengan persentasi $90 \%$ yang termasuk kedalam ketegori "Sangat Baik". Komentar dan saran dari validator pada tahap ke-I diperbaiki untuk tahap ke-II.

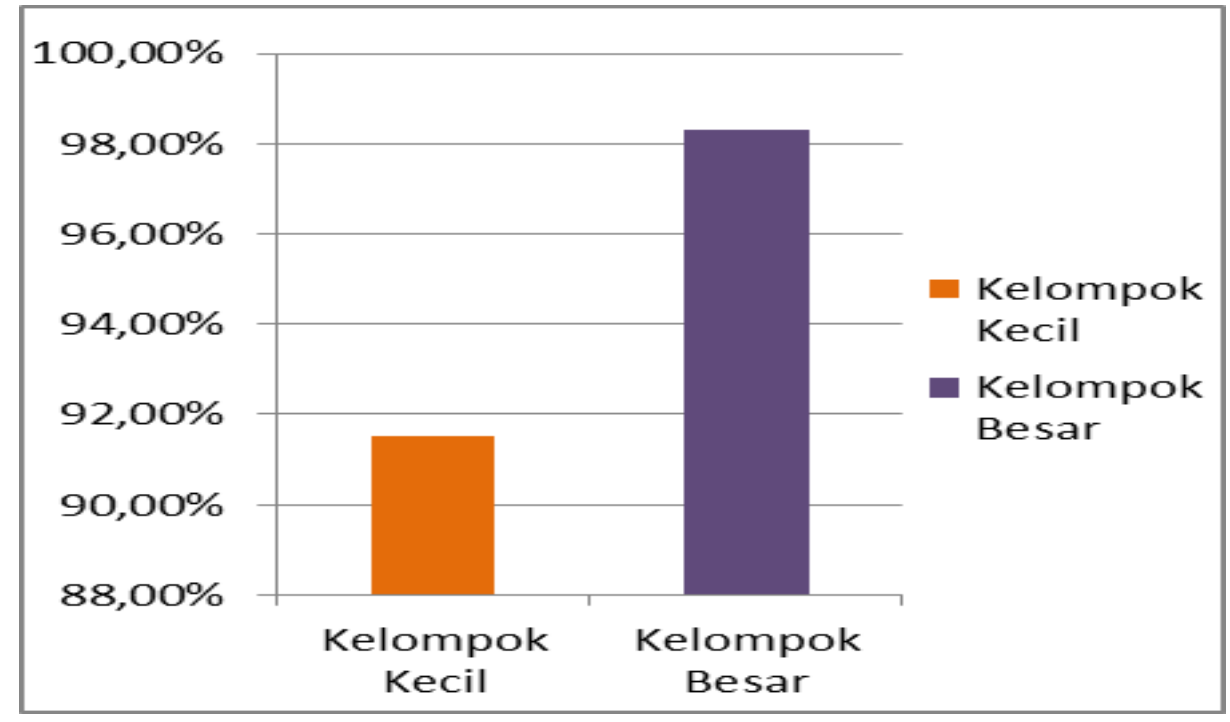

Gambar 3. Ujicoba produk pada kelompok kecil dan kelompok besar

\section{c. Respon Kelompok Kecil dan Kelompok Besar}

Tahap implementasi (ujicoba) booklet pada kelompok kecil untuk melihat keterbacaan sebelum dilakukan uji pada kelas yang sebenarnya. Fungsi tahap implementasi ini yaitu melihat kepraktisan dari booklet budidaya jamur edible. Kepraktisan dilakukan dengan melakukan ujicoba kepada mahasiswa yang mengontrak mata kuliah mikologi. Ujicoba booklet dilakukan setelah dinyatakan layak atau valid untuk digunakan dari tim validasi (validasi materi dan validasi media). Mahasiswa yang mengontrak mata kuliah mikologi akan diminta untuk membaca dan mempelajari booklet yang sudah diberikan. Setelah itu, mahasiswa akan diberikan angket untuk mereka isi untuk melihat kepraktisan booklet. Adapun tingkat kepraktisan booklet yang dilihat dari hasil respon mahasiswa setelah booklet budidaya jamur edible antara lain sebagai berikut:

Berdasarkan hasil uji yang dilakukan kepada mahasiswa pendidikan biologi Fakultas Keguruan dan IImu Pengetahuan Universitas Jambi didapatkan hasil antara lain untuk ujicoba kelompok kecil yang terdiri atas 8 mahasiswa pendidikan biologi yaitu 91,5\% yang termasuk kedalam ketegori "Sangat Baik". Sedangkan hasil ujicoba kelompok besar terhadap 24 orang mahasiswa pendidikan biologi yaitu 98,3\% yang termasuk kedalam ketegori "Sangat Baik".

\section{d. Persentase Hasil Pengembangan}

Berdasarkan hasil analisis data yang dimulai dari serangkaian proses penilaian baik dari validasi media dan validasi materi, serta hasil ujicoba kelompok kecil dan kelompok besar mahasiswa pendidikan biologi, kemudian didapatkan hasil keseluruhan dari media booklet budidaya jamur edible dapat dilihat pada gambar 4 . 


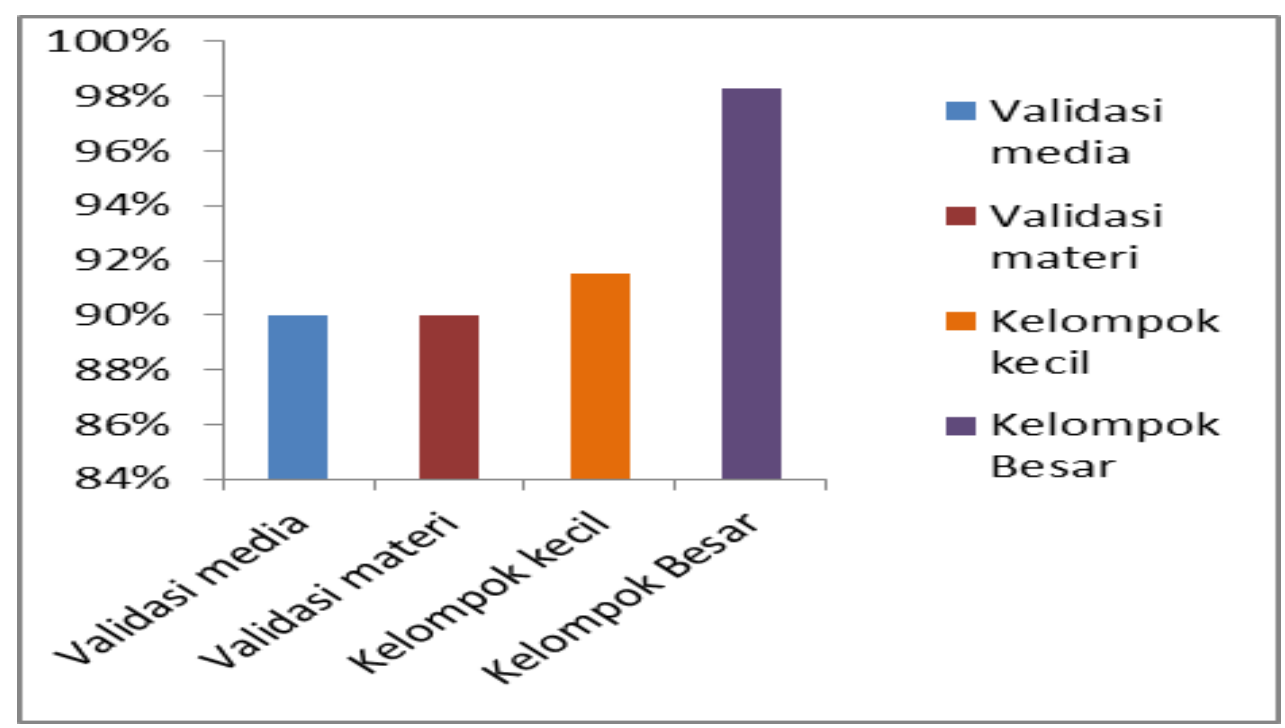

Gambar 4. Persentase hasil pengembangan

Berdasarkan gambar 4 diketahui bahwa validasi media ini dilakukan sebanyak dua kali, validasi tahap I dengan skor $75 \%$ termasuk kategori "sangat baik", dan produk masih banyak saran dan perbaikan. Revisi ditekankan pada penulisan, tampilan gambar dan tata letak gambar. Selanjutnya dilakukan perbaikan dan dilakukan validasi tahap ke-2 dengan hasil $90 \%$ termasuk kategori "sangat baik" tahap ini media sudah layak untuk ujicoba. Hasil validasi materi juga dilakukan dengan 2 tahap yaitu pada tahap ke-1 mendapatkan skor 70\% yang termasuk kategori "baik" dan produk masih ada kesalahan baik dari penulisan dan ada beberapa materi yang ditambahkan. Selanjutnya dilakukan perbaikan dan dilakukan validasi tahap ke-2 dengan hasil 90\% termasuk kategori "sangat baik", pada tahap ini produk sudah siap untuk diujicobakan.

Validasi dilihat dari beberapa aspek antara lain komponen materi, kelengkapan materi, petunjuk penggunaan, dan evaluasi materi yang dikembangkan. Setelah semua unsur telah terpenuhi maka tim validator akan menyatakan produk tersebut sudah sangat layak "valid" dan sudah dilakukan ujicoba kepada peserta didik. Menurut Rohaeti dan Padmaningrum (2009) menyatakan bahwa indikator kevalidan media pembelajaran terdiri atas menekankan pada proses untuk menemukan konsep, ada variasi stimulus melalui berbagai media dan kegiatan peserta didik, dan mengutamakan pada pengembangan kemampuan, komunikasi, sosial, emosional, moral dan estetika.

Selain itu, produk yang dihasilkan ini harus bisa menarik minat belajar peserta didik antara lain dengan cara menampilkan gambar pada produk booklet tersebut. Gambar sangat dibutuhkan untuk mendukung dan memperjelas isi dari materi pembelajaran, karena disamping akan memperjelas isi materi, gambar juga dapat memperjelas uraian serta dapat menambah daya tarik peserta didik dan mengurangi kebosanan pada peserta didik (Prastowo, 2011).

Setelah dilakukan validasi oleh tim validator, selanjutnya dilakukan ujicoba pada peserta didik mulai dari kelompok kecil (8 orang) dan kelompok besar (24 orang). Berdasarkan hasil ujicoba yang dilakukan terhadap kelompok kecil yang berjumlah 8 orang mahasiswa pendidikan biologi Fakultas Keguruan dan IImu Pengetahuan Universitas jambi didapat hasil yaitu 91,5\% dengan kategori "sangat 
baik". Sedangkan hasil ujicoba kelompok besar yang berjumlah 24 orang mahasiswa pendidikan biologi didapat hasil yaitu 98,3\% dengan kategori "sangat baik".

Berdasarkan hasil ujicoba tersebut bahwa produk booklet yang dikembangkan secara keseluruhan sangat baik atau sangat praktis digunakan. Hal ini dikarenakan peserta didik merasa mudah dalam menggunakan booklet budidaya jamur edible karena telah disertai materi dan gambar yang menarik. Selain itu booklet budidaya jamur edible menggunakan bahasa yang mudah dipahami oleh semua kalangan baik mahasiswa, pelajar dan masyarakat umum.

Kemudahan peserta didik dalam memahami materi pembelajaran dengan menggunakan booklet budidaya jamur edible didukung dengan gambar yang mudah dipahami, adapun tujuan dari gambar tersebut yaitu untuk mengarahkan peserta didik untuk dapat fokus pada materi, sehingga berpengaruh pada tingkat pemahaman peserta didik dalam memahami materi pembelajaran. Hal tersebut juga dinyatakan Firdaus dan Wilujeng (2018) respon positif pada peserta didik terhadap media pembelajaran disebabkan oleh peserta didik dapa memahami atau mengerti maksud masalah yang terdapat dalam media pembelajaran, selain itu, peserta didik juga memahami langkah kerja yang terdapat pada media, serta pada lembar kegiatan terdapat gambar atau ilustrasi yang dapat diamati untuk memudahkan peserta didik dalam memahami materi pembelajaran.

\section{e. Tahap Evaluasi (Evaluation)}

Tahap ini dilakukan pada setiap langkah dipengambangan booklet sebagai upaya perbaikan yang bertujuan untuk memperbaiki setiap langkah yang dilakukan. Sehingga, proses evaluasi dan refleksi memudahkan untuk memperbaiki setiap tahap yang sebelumnya. Adapun hasil evaluasi yang dilakukan sebagai masukan validator antara lain sebagai berikut:

Tabel 1. Saran dan revisi

\begin{tabular}{|l|l|}
\hline \multicolumn{1}{|c|}{ Saran } & \multicolumn{1}{|c|}{ Revisi } \\
\hline $\begin{array}{l}\text { Secara keseluruhan sudah cukup baik dan layak } \\
\text { digunakan. Tetapi pada beberapa bagian perlu } \\
\text { ditambah dengan materi yang aplikatif dan disertai } \\
\text { gambar }\end{array}$ & $\begin{array}{l}\text { Penambahan materi dan beberapa gambar yang } \\
\text { memperjelaskan materi yang ada. }\end{array}$ \\
\hline $\begin{array}{l}\text { Cover perlu diperbaiki dengan gambar yang sesuai } \\
\text { dengan pembahasan booklet. }\end{array}$ & $\begin{array}{l}\text { Cover didesain semenarik mungkin dengan merubah } \\
\text { gambar yang sesuai dengan pembahasan materi booklet. }\end{array}$ \\
\hline Tata tulis pada booklet masih ada yang perlu diperbaiki & $\begin{array}{l}\text { Tata tulisan setiap sub babnya telah diperbaikin dari } \\
\text { kesalahan sesua dengan EYD. }\end{array}$ \\
\hline $\begin{array}{l}\text { Gambar yang belum jelas pada booklet masih ada } \\
\text { yang belum terlalu jelas }\end{array}$ & $\begin{array}{l}\text { Memperbaiki atau mengganti gambar-gambar yang belum } \\
\text { jelas menjadi lebih jelas dan mudah dipahami oleh } \\
\text { pembaca }\end{array}$ \\
\hline
\end{tabular}




\section{KESIMPULAN}

Berdasarkan hasil penelitian pengembangan yang telah dilakukan dapat disimpulkan bahwa : (1) pengembangan booklet budidaya jamur edible pada mata kuliah mikologi bagi mahasiswa Pendidikan Biologi menggunakan model Analysis, Design, Development, Implementation, Evaluation (ADDIE). (2) Kevalidan booklet budidaya jamur edible dilihat dari validasi materi dan validasi media, hasil validasi yang dihasilkan yaitu $90 \%$ dan booklet ini dikategorikan sangat baik. (3) Kepraktisan booklet budidaya jamur edible berada pada kategori sangat praktis dengan nilai rata-rata $91,5 \%$ hasil uji coba kelompok kecil dan $98,3 \%$ untuk ujicoba kelompok besar.

\section{DAFTAR PUSTAKA}

Achmad, M., Arlianti, T., dan Azmi, C. 2013. Panduan Lengkap Jamur. Jakarta: Penebar Swadaya Arsyad dan Azhar. 2011. Media Pembelajaran. Jakarta: PT Raja Grafindo Persada

Depdiknas. 2008. Panduan Pengembangan Bahan Ajar. Jakarta: Direktorat Pembinaan Sekolah Menengah Atas.

Dikti. 2009. Pedoman Operasional Penilaian Angka Kredit Kenaikan JabatanFungsional Dosen ke Lektor Kepala dan Guru Besar. Jakarta:Kemendiknas

Firdaus, M dan Wilujeng, I. 2018. Pengembangan LKPD inkuiri terbimbing untuk meningkatkan keterampilan berpikir kritis dan hasil belajar peserta didik. Jurnal inovasi pendidikan IPA. 4(1): 2640

Mintarti. 2011. Efektifitas Booklet Makjan Sebagai Media Pembelajaran Untuk Meningkatkan Perilaku Berusaha Bagi Pedagang Makanan Jajanan. Tesis: ITB. Bogor

Pralisaputri K. R., Soegiyanto H., Muryani C. 2016. Pengembangan Media Booklet Berbasis SETS Pada Media Pokok Mitigasi dan Adaptasi Bencana Alam Untuk Kelas X SMA. Jurnal GeoEco, 2(2): 147-154.

Prastowo, A. 2012. Panduan Kreatif Membuat Bahan Ajar Inovatif. Yogyakarta:DIVA Press

Pratowo, A. 2011. Pengembangan Bahan Ajar Tematik; Tinjauna Teoritis dan Praktis. Jakarta: Kencana Prenadamedia Group.

Riduwan. 2011. Belajar Mudah Penelitian untuk Guru, Karyawan, dan Peneliti Pemula. Bandung: alfabeta.

Rohaeti, E., LFX, E.W dan Padmaningrum, R.T. 2009. Pengembanagan lembar kerja siswa (LKS) mata pelajaran sains kimia untuk SMP. Jurnal Inovasi Pendidikan. 10(1).

Suwarni, E. 2015. Pengembangan Buku Ajar Berbasis Lokal Materi Keanekaragaman Laba-Laba Di Kota Metro Sebagai Sumber Belajar Alternatif Biologi Untuk Siswa SMA Kelas X. Jurnal Bioedukasi Vol. 6(2):13-22. 